\title{
Professionalism Dismissed?
}

Librarianship is not a profession. Most librarians fail to meet, for want of substantive knowledge, the three measures of professional functions: significant service to clients, maintenance of independent judgment within institutional settings, and union with colleagues in a strong organization to ensure effective work. Paradoxically, the very failure in knowledge, and the consequent want of status, responsibility, and income, produce insecurity and the emotional need to compensate with the title "professional." Yet librarians' work manifests no profession of faith in bettering the human condition, no pursuit of excellence in knowledge and service. Most librarians are and will be advanced technicians until library education is considerably improved.

$S$ Since Melvil Dewey confidently afFIRMED that librarians are "professionals," a great cry of agreement has periodically flared in round after round of books and articles, all authored by librarians themselves. ${ }^{1}$ These books and articles generally manifest enthusiastic, if not hysterical support for Dewey's assertion. Unfortunately such writings are too reminiscent of the many essays in which male librarians defend their masculinity; that is, writings on both subjects tend to present extravagant claims and little evidence.

Large claims and small evidences betray librarians' uncertainty about their assumption of the professional title. The continued repetition of those large claims for several generations suggests that the uncertainty runs through the entire history of modern librarianship. Large claims offered again and again without proof imply that the librarians' claim to professionalism is a nonrational, emotional need for status. Apparently, like the medicine men of old and the politicians of the present, librarians

Mr. Flanagan is a student at Simmons College, School of Librarianship, Boston, Massachusetts. assuage their doubts and confirm their beliefs in a proposition simply by repeating it. By ceremonious repetition the proposition eventually assumes the qualities of a religious chant.

But the librarians' belief in their professionalism, unlike a religious belief in grand universal directions, is a mean faith in their own self-importance, proceeding from a realization (probably unconscious) of some personal insecurity, in power, reputation, income, knowledge, or human commitment; and from an acute need to compensate for the insecurity caused by the assumption of a status higher than one earned. ${ }^{2}$

As a librarian-to-be, I feel duty-bound to attack the myth that librarianship is a profession, because it has no reasonable or scientific justification nor is one expected, and because it hurts librarians themselves. In short, the myth of professionalism allows them to live in a dream world, seeing themselves as redeemers of men, noble intellectual martyrs, the equals of society's great men. In actuality they are low men in salary, prestige, training, and genuine service to people.

A hard and clear definition of the word "professional" would settle the 
claim of librarians at once. Harold Lancour maintains that librarianship is a profession, just barely. ${ }^{3}$ Bundy and Wasserman assert it is a profession, marginally. ${ }^{4}$ Both of these conclusions are curious in so far as they do not quite follow, especially in the Bundy and Wasserman case, from the evidence presented. Bundy and Wasserman in particular pose a clear and realistic definition of the word professional, a definition that would appear to exclude most librarians. They maintain that one's professionalism is determined by one's maintenance of three basic relationships. First, the professional must have the correct client relationship; i.e., he must undertake to serve other human beings. Second, he must have the correct institutional relationship; i.e., he must be able to exercise his individual judgment freely in his field with no danger of giving offense to his institution. Third, he must have the correct professional group relationship; i.e., he must be a strong member of an effective professional association. The average librarian does not seem to satisfy all three relationships.

\section{The Client Relationship}

A characteristic deficiency of librarians is a lack of substantial specialized service. Librarians are compelled to keep their service simple because, according to Bundy and Wasserman, they simply lack "substantive knowledge" of their fields; therefore, they have little or nothing to serve to their clients, except tangible goods, books as objects.

Librarians hide behind technique and clerical work to avoid exposure to clients. The librarian exercises no real authority with his clients; his judgment could never command the respect of a client that a doctor's or lawyer's would. Paul Dunkin comments:

Well, let's look at your doctor and your lawyer as a pair and your librari- an and my grocer as a pair. Each pair answers the needs of its users-or clients if you prefer the word. The doctor and the lawyer decide what their clients need even though what they decide may not be what their clients want. The doctor may prescribe a diet and the lawyer may advise his client to confess. The librarian and the grocer give their clients what they want even though they may know that this is not what their clients need. If the fat man wants a pie, a pie he gets; if the boy flunking chemistry wants a sports story, a sports story is what he gets. ${ }^{5}$

As Bundy and Wasserman observe, if the librarian bears a resemblance to any medical person it is to the druggist, who has little if any knowledge of his customers' ills and only the most superficial knowledge of his medicines. ${ }^{6}$

Given the crises of this age, librariians' concern with forms, methods, and technicalities must give way to a concern for people. Librarians must look to the reference function, to the "innards" of books, and to people-lest like Borges' librarian in The Library of Babel they have all the books imaginable at hand but can give to no man even one volume to help him understand his life and his universe. Librarians must realize that this is the time of Martin Buber's IThou relationships, the time of an earnest striving after human contact, after contact with the souls of men in books and bodies.

The essence of a profession is the act of professing, of believing, of actively avowing, of growing in a faith, in basic principles about man and his universe. A profession is a constant religious faith; a professional is a priest of that faith. For a millenium and a half all professionals were clerics.

The dogmas of a librarian's faith, were he a professional, would be simple and few. Men exist; they are occasionally reasonable; they can communicate reasonably through various media from 
pictographs to computers; it is better that they communicate reasonably than that they do not; someone should study men and the media of reasonable communication to see how the two are related and how the relation may be improved; and someone should and can undertake the function of doing the relating, so that men may grasp fact (information) and truth (the meaning of fact) good and necessary for them, their brethren, their world. With these beliefs a professional librarian would actively seek personal growth through a lifetime of training in theoretical and practical knowledge. Initially such training would be formal; later it would occur through special agencies, conferences, and institutes, as well as through self-study, experience, observation, criticism, research, and creative constructive work.

Rich in knowledge and wisdom, the librarian as professional, with deep faith in the religious articles listed above, would want to serve his fellow men, and would actually have something with which to serve him. The person with such beliefs, knowledge, and motivation to serve, would expedite communication among men rather than hinder it. We would have no more horror tales like the recent Bucknell University one, for librarians would have the self-respect to stand up vigorously against such nonsense from the government. ${ }^{7}$ We would hear no more charges so shameful as those from Marjorie Fiske about the librarians' own crude censorship in California. ${ }^{8}$ We would not have David Berninghausen telling us that there is no reason to suppose library students have read Mill or Milton. ${ }^{9}$ We would not hear from R. W. Conant that librarians are not trained to manage metropolitan library systems and that some major changes must be made in library education. ${ }^{10} \mathrm{We}$ would not hear from Elizabeth Stone that 25 percent of all librarians did not read a library-science book in the past year, or about the 77 percent who have done no research project since graduate school. ${ }^{11}$ We would not hear from Robert Leigh that only 10 percent of the population finds the public libraries worthwhile enough to use regularly. ${ }^{12} \mathrm{We}$ would not hear from Helen Brown that only 14 percent of librarians in American colleges and universities can get full faculty status. ${ }^{13}$ And we would not hear W. Stanley Hoole quoting Dr. Thomas Bray's Bibliothecae Americanae to the effect that it is impossible to believe that those in charge "should be able to communicate to others, what they are not themselves first become masters of," and asserting that librarians are still the lackeys, not the masters, of books. ${ }^{14}$

When librarians acquire professional faith and professional competence, there will be a real service relationship with clients, and the regular indictments of their continuing ineptitudes would cease. So too, many of the critical articles, such as this, would cease to be written, and we would all have much less negative material to read-a distinct, albeit a peripheral, advantage.

\section{The Institutional Relationship}

As Bundy and Wasserman note, the true professional exercises independent judgment in the areas of his special knowledge, though he may work within an institution and be paid by same. ${ }^{15}$ For while the professional serves the client, his institution serves the professional to help him help the client. For example, no hospital administrator can challenge the youngest doctor's prescription for a patient. Medical doctors are independent in their institutional relationships because of the excellence of their knowledge and service. They have risen to the highest levels of professionalism from that time only a century ago when they were considered at best good 
barbers, at worst, dangers to the commonweal, fatally inept quacks, and charlatans in their communities.

What self-determination, what independence of judgment does the librarian exercise within his institution? Paul Dunkin again has an answer for us:

The doctor and the lawyer perform their services within the framework set by their training, their experience, their profession, and their judgment; the grocer and the librarian perform their services within the framework of their training, their experience, their profession, and their bosses' decisions. Unless, of course, the grocer and the librarian happen to be the bosses themselves. ${ }^{16}$

Bundy and Wasserman declare that the librarian exercises plenty of independence, but unfortunately in regard to the patron rather than the institution..$^{17}$ Library institutions emphasize little independent judgment and much loyalty to the library administrator and to the institutional status quo. The Code of Ethics for Librarians, by its very tone, suggests that librarians should not rock the boat-at least, not without an order from the captain. ${ }^{18}$ Article one of the Code stresses the librarian's obligation, not to know, criticize, or independently judge, but to submit to "governing authority," to "the library constituency," and to "the library as an institution." Item two emphasizes that the librarian is employed by his institution as a hired worker. Item three takes away any right to benefits that might accrue to a librarian assuming the status of hired worker.

Articles four to eight of the Code define a way of life for the librarian in no way observedly different from that of a factory employee. In the last part of the Code there is some talk of "initiative," and "criticism"-a librarian should be careful not to seize initiative, however, until it has been delegated to him. And criticism may be offered only to the "proper authority." The rules of a monastery would hardly be more restrictive than those of the librarians' Code of Ethics. Even the "point of view" of the Code is unprofessional, for the librarian is told twenty-eight things he "should" do. The American Library Association itself views librarians (with the exception of the few who are directors, of course) simply as employees, with little right of autonomous judgment. The problem is analogous to a growing problem in college teaching, in which the administration denies individual judgment and decision to the faculty on matters of any importance to their teaching.

Professionalism implies effectiveness in reaching one's goal of serving others in some way, effectiveness acquired by training, independence of judgment, an ethical obligation, and a national organization. Professionalism, in short, implies the power to do what one says one wants to do.

Librarians should be professionally efficient in selecting the best means of communication, in choosing quality materials from a mass of growing publications, in judging new media and technologies, in deciding new systems, in estimating new patron needs. They should be professionally effective in finding money and spending it. They should be professionally able to divert those forces which would hinder communications in this time of most critical problems: the government spies, the self-appointed censors, and shifty, electionminded politicians. And they should even be effective at acquiring the broad knowledge they require to be effective in all these other areas.

W. Stanley Hoole asserts that the fault for librarians' want of knowledge lies in the one year programs of the library schools. ${ }^{19}$ Library courses occupy only a year of study; many courses offer a historical or descriptive approach rather than a critical one, par- 
ticularly the "core" courses, referred to as the "rotten core."20 David Berninghausen wants more study of the classics on freedom of thought and speech. ${ }^{21}$ Robert Hayes has asked for administrative courses in market research, program planning, research and design, personnel management, and budgeting. ${ }^{22}$ $\mathrm{He}$ also wants more information scientists and information specialists. Other critics have asked for courses on human relations, general business management, systems analysis, history, economics, social psychology, psychology, any study that might aid the librarians in getting to know their patrons better. To these I would add: an internship in a library (if possible, one with a critical problem); a course in the philosophy of librarianship; a course in important contemporary books from Malcolm X to Ivan Illich; a course in literary or general scientific criticism. These might stimulate a lifelong interest in reading and research.

Whatever curriculum reforms are emerging, all seem to urge a deeper and longer library-school education. The one year general graduate program now offered by library schools should not, and does not, confer professional knowledge. In the special case of the librarian, further education is necessary because of the critical need for human communication, because of the present problems that make such communication difficult, because those problems are likely to increase in the near future, and because problems of communication are particularly appropriate to the librarian.

\section{The Professional Group Relationship}

The American Library Association is notoriously weak, so much so that one can have nightmares imagining what a medical doctor in a malpractice suit would do if he were backed only by ALA. To paraphrase Bundy and Was- serman: theory, philosophy, and ethics have been evaded by ALA; it has avoided improving standards for accredited library schools; it does not press its average member to keep up in the field or maintain national relationships; it is held together by a few strong people who work not as professionals for the profession but as politicians to preserve their own hierarchy. ${ }^{23}$ Until librarians have more than a general level of training, until they perform genuine public service on a wide scale, and until they develop independence in pursuit of their goals, they will not establish a strong national organization, nor will they see the necessity of doing so.

To make themselves professionals, librarians must demand library-school reforms in admissions and curricula. My fear is not that reforms will not be made in the library schools, and then consequently in the field as a whole. My fear is that the reforms will not be made quickly enough, that librarians of today will jealously turn away brighter people who might make them uncomfortable tomorrow. My fear is that librarians will maintain their characteristic genteel poise between commitments while big unions and big business and big government and big electronic media take over libraries and librarians' functions. Then librarians, if they remain at all, will become civil slaves, and freedom of thought and speech and criticism will have been extinguished. The humane tradition will have been buried, and librarians will have lifted their spadeful of earth.

\section{REFERENCES}

1. Melvil Dewey, "Librarianship as a Profesfession," In: Of, By, and For Librarians, John David Marshall, ed. (Hamden, Conn.: Shoestring Press, 1960) p. 179-81; reprinted from Library Journal 84:25-26 (1 Jan. 1959).

2. Harold Lancour, "The Librarians' Search for Status," Library Quarterly 31:369-79 
(Oct. 1961). Reprinted in Seven Questions about the Profession of Librarianship. Philip Ennis and Howard Winger, eds. (Chicago: Univ. of Chicago Press, 1962).

3. Ibid.

4. Mary Lee Bundy and Paul Wasserman, "Professionalism Reconsidered," CRL 29: 5-26 (Jan. 1968).

5. Paul Dunkin, "Fresh Eggs Anyone?" In his Tales of Melvil's Mouser (New York: Bowker, 1970), p. 70.

6. Bundy and Wasserman, "Professionalism ...," p. 8.

7. Paul Cowan, "Bearing Witness," Library Journal 97:2150-52 (15 June 1972).

8. Marjorie Fiske, Book Selection and Censorship: A Study of School and Public Libraries in California (Berkeley and Los Angeles: Univ. of California Press, 1968).

9. David Berninghausen, "Teaching a Commitment to Intellectual Freedom," Library Journal 92:3601-5 (15 Oct. 1967).

10. R. W. Conant, "Future of the Public Libraries," Wilson Library Bulletin 44:544 9 (Jan. 1970).

11. Elizabeth Stone, Factors Related to the Professional Development of Librarians (Metuchen, N.J.: Scarecrow Press, 1969).

12. Robert D. Leigh, The Public Library in the United States: The Report of the Public
Library Inquiry (New York: Columbia University Press, 1950).

13. Helen Brown, "Personnel and Manpower Needs for the Future: Trends in College Librarianship," H. Vaile Deale, ed., Library Trends 18:75-84 (July 1969).

14. W. Stanley Hoole, "Of the Librarian's Education," In: Of, By and For Librarians John David Marshall, ed. (Hamden, Conn.: Shoestring Press, 1960), p. 240-50.

15. Bundy and Wasserman, "Professionalism ...," p. 15.

16. Dunkin, "Fresh Eggs ...,", p. 72.

17. Bundy and Wasserman, "Professionalism ...," p. 14.

18. "Code of Ethics for Librarians," ALA Bulletin 33:128-30 (Feb. 1939).

19. Hoole, “. . . Librarian's Education,” p. 243 50 .

20. J. E. Daily, "Teaching the Rotten Core," Library Journal 97:1778-83 (15 May 1972).

21. Berninghausen, "Teaching a Commitment ....," p. 1305.

22. Robert Hayes, "Commentary," Student Use of Libraries: An Inquiry into the Needs of Students, Libraries and Educational Process (Chicago: ALA, 1964).

23. Bundy and Wasserman, "Professionalism ... ," p. 25. 